\title{
Regulation of E-cadherin: does hypoxia initiate the metastatic cascade?
}

\author{
I R G Beavon
}

\begin{abstract}
The ability of tumours to metastasise is regarded as one of the hallmarks of malignancy. The process through which tumours evolve to achieve this has been termed the metastatic cascade. This cascade has been the subject of much investigation over many years. One of the vital events identified by these investigations is the reduction of adhesion between tumour cells facilitating invasion of the surrounding tissues and vascular channels, ultimately leading to the development of a distant metastasis. E-cadherin and its associated catenin complex have been identified as key molecules in cell adhesion. This review looks at the structure and interaction of the $\mathrm{E}$-cadherin-catenin complex and the factors that appear to regulate $E$-cadherin expression and thus cell adhesion. From the data gathered, it has become possible to propose the hypothesis that the development of tumour hypoxia is the initiating factor that sets the tumour on the road to metastasis. (F Clin Pathol: Mol Pathol 1999;52:179-188)
\end{abstract}

Keywords: E-cadherin; cell adhesion; hypoxia; tumour necrosis

The ability of tumour cells to invade adjacent tissues and disseminate to distant organs has long been considered the biological hallmark of malignancy. This ability of malignant tumours to colonise and destroy distant organs was first recognised by Jean-Claude Recamier in 1829 and termed metastasis. ${ }^{1}$ Since this first basic but profound observation, the study of the mechanisms and importance of metastasis has formed an important part of the investigation of neoplasia. The expansion of this body of knowledge has been particularly rapid over the past two decades, coinciding with the development of new techniques that have allowed crucial insights into the interplay of various factors at a molecular and genetic level. The resultant model shows metastasis to be a coordinated, multistep process encompassing the detachment of cells from the primary tumour to the development of a tumorigenic lesion in a distant site (fig 1). ${ }^{23}$

The process of metastasis appears to be regulated by a variety of gene products. ${ }^{4}$ These include: (1) cell-cell and cell-extracellular matrix receptors ${ }^{5}$; (2) proteolytic enzymes that facilitate the breakdown and invasion of the basement membrane, vascular channels, and organs $^{7-9}$; (3) motility factors that allow migration through tissues ${ }^{10}{ }^{11}$; (4) receptors mediating organ specific invasion ${ }^{12}$; (5) growth factors necessary for the maintenance of the tumour microcolonies in the secondary organ ${ }^{13}$; and (6) angiogenic factors that result in neovascularisation of the metastasis, allowing the supply of nutrients, removal of metabolites, and haematogenous spread of metastatic cells. ${ }^{14}{ }^{15}$ Consequently, it can be appreciated that the weakening of cell-cell adhesion mechanisms must be a basic prerequisite for tumour metastasis to occur. The weakening involves changes in homotypic cell-cell adhesion, heterotypic cellcell adhesion, and interactions of cells with the extracellular matrix at the primary tumour site. ${ }^{16}$ In recent years, several families of biochemically and genetically distinct cell adhesion molecules have been described. These include the cadherins, integrins, adhesion molecules belonging to the immunoglobulin superfamily, selectins, and CD44.

The members of the cadherin family of cellcell adhesion molecules are situated on the cell surface and have a wide distribution in normal tissues. Although the family as a whole shows a wide distribution, the individual members show pronounced tissue specificity. E-cadherin is one of the best characterised members of the family and is expressed by all normal epithelia. It has been the focus of much attention recently because of its apparent promise as a prognostic indicator, with loss or reduction of expression correlating with enhanced aggressiveness and dedifferentiation of many carcinomas. ${ }^{17-22}$ In this paper, the E-cadherin adhesion system and its relation to the metastatic potential of tumours will be reviewed.

\section{Structure and function of the}

\section{E-cadherin-catenin complex}

To appreciate the role of the E-cadherincatenin complex it is essential to be familiar with the interactions of these molecules and the mechanisms by which they exert their effects.

E-cadherin is a transmembrane protein with a molecular mass of $120 \mathrm{kDa}$. It is formed from a $135 \mathrm{kDa}$ precursor, which undergoes cytoplasmic enzymatic trimming to form the mature molecule and is then routed mainly towards the basolateral surface of the epithelial cells, where it tends to localise to specialised junctions of the zonula adherens type (fig 2). ${ }^{23}{ }^{24}$ The enzymatic trimming of the precursor at the extracellular N-terminal end of E-cadherin is essential for the mature molecule to exert its role in cell-cell adhesion. ${ }^{25}$ The gene encoding human E-cadherin has recently been cloned and characterised. ${ }^{26}$ It has been found to be situated on chromosome 16q22.1, within a large conserved linkage group that includes loci for haptoglobin, chymotrypsinogen $\mathrm{B}$, 


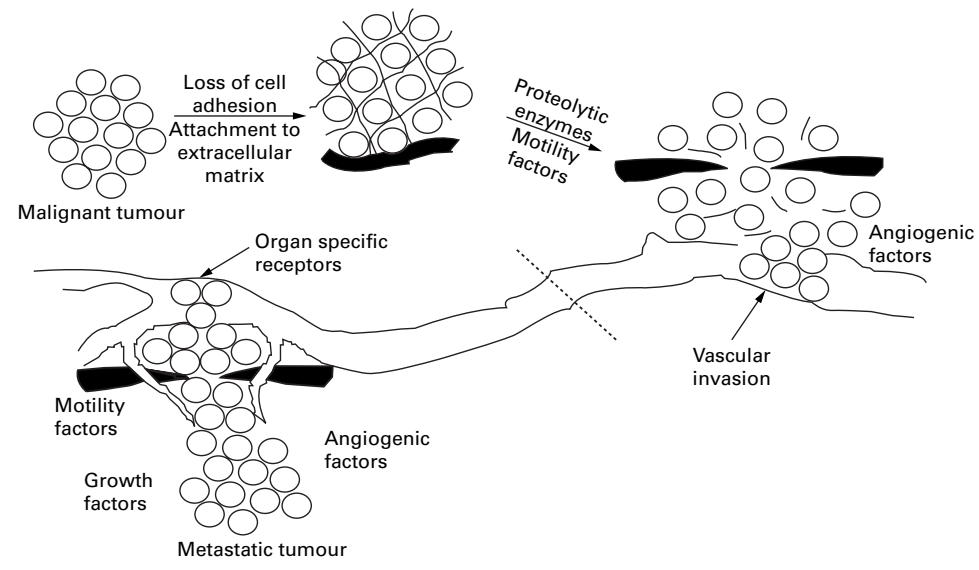

Figure 1 The multistep process of metastasis.

metallothionine-1, metallothionine-2, tyrosine aminotransferase, and lecithin cholesterolacyltransferase..$^{27} 28$

E-cadherin consists of an extracellular domain, which binds homotypically to E-cadherin molecules on adjacent cells, and a highly conserved intracellular domain, which binds non-covalently to the catenins. The homotypic binding is calcium dependent and is mediated by five homologous repeated domains that harbour two conserved regions representing the putative calcium binding sites..$^{29} 30$ The extracellular domain also possesses a flexible hinge region. ${ }^{31}$ The cytoplasmic domain of E-cadherin contains a highly conserved region that is common to all members of the cadherin family. ${ }^{32}$ The presence of this region provides a target for immunological screening for the presence of cadherins. There is a catenin recognition site within the cytoplasmic domain that forms the link to the cytoskeleton through its interaction with the catenin complex. ${ }^{334}$ The two parts of the molecule are connected by a single, 32 amino acid, hydrophobic, membrane spanning domain. ${ }^{31}$
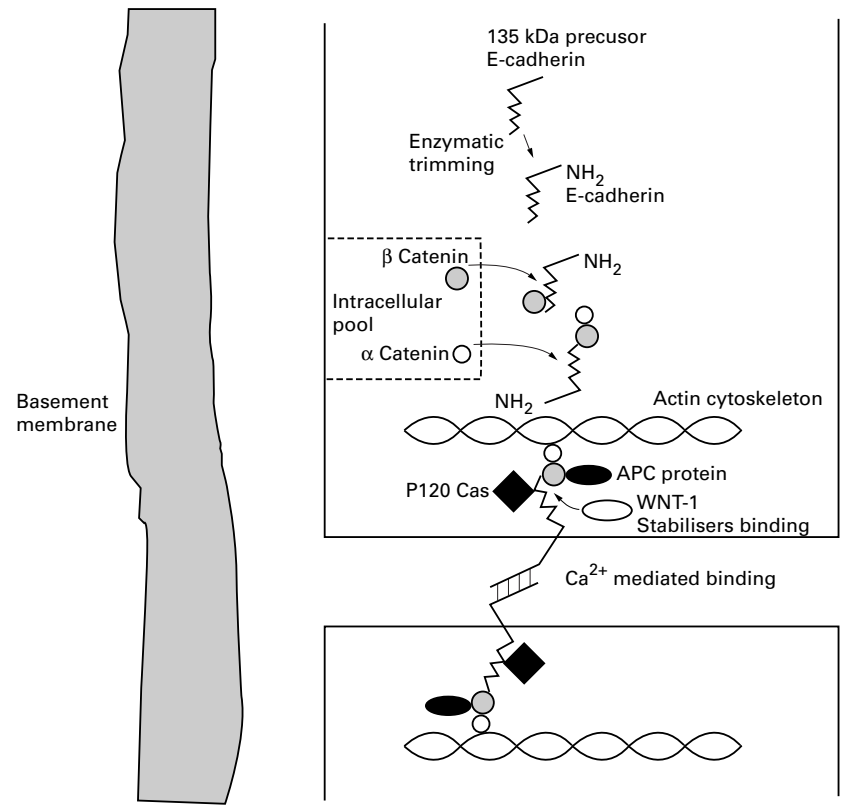

Epithelial cell

Figure 2 The formation of an E-cadherin complex using a catenin and $\beta$ catenin in epithelial cells.
The binding of the transmembranous E-cadherin molecule and the actin cytoskeleton is essential for the formation of strong cell-cell adhesion mediated by the catenins, a series of associated cytoplasmic proteins that are classified according to their molecular weight. The catenin complex consists of $\alpha$ catenin $(102 \mathrm{kDa}), \beta$ catenin $(92 \mathrm{kDa})$, and $\gamma$ catenin/plakoglobin $(83 \mathrm{kDa}) .^{35-37}$ The human genes have been assigned for all three catenins, with $\alpha$ catenin located on chromosome $5 \mathrm{q} 31, \beta$ catenin on chromosome $3 \mathrm{p} 21$, and $\gamma$ catenin/ plakoglobin on chromosome $17 \mathrm{q} 21 . .^{38-40} \mathrm{~A}$ fourth catenin-like molecule, p120cas, has recently been described and its gene localised to the long arm of chromosome $11 \mathrm{q} 11$, immediately adjacent to the centromere. ${ }^{41}{ }^{42}$ The protein has been shown to be a tyrosine kinase substrate for epidermal growth factor (EGF) and platelet derived growth factor (PDGF) receptors. ${ }^{43}$ Four isoforms of the p120cas molecule have been described.

The catenins bind to E-cadherin and each other in a specific manner. E-cadherin binds to either $\beta$ catenin or $\gamma$ catenin, whereas $\alpha$ catenin also binds $\beta$ catenin or $\gamma$ catenin but not E-cadherin. ${ }^{446}$ The existence in the same cell of two distinct E-cadherin-catenin complexes results from specific binding. One complex is composed of E-cadherin, $\alpha$ catenin, and $\beta$ catenin, and the other of E-cadherin, $\alpha$ catenin, and $\gamma$ catenin. ${ }^{46}$ The p120cas molecule appears to bind only to E-cadherin and does not associate directly with the other catenins or the $300 \mathrm{kDa}$ adenomatous polyposis coli (APC) protein, which binds to $\beta$ catenin. ${ }^{48-50}$ The wild-type (wt) and the mutated (mt) APC proteins both bind to $\beta$ catenin..$^{48}$ Several other cytoplasmic molecules have been found to associate with the E-cadherin-catenin complex. Among these is the wnt- 1 gene product, which has been found to initiate a mechanism by which the binding between E-cadherin and $\beta$ catenin is stabilised, effectively promoting cell-cell adhesion. ${ }^{51}$ The c-erbB-2 gene product has also been found within the complex as a result of binding to $\beta$ catenin or $\gamma$ catenin. ${ }^{52}$

The E-cadherin-catenin complex begins to form during the passage of E-cadherin to the cell membrane. The first catenin to interact with E-cadherin is $\beta$ catenin. ${ }^{46}{ }^{53}$ The initial interaction is followed by binding of $\alpha$ catenin to a short region close to the $\mathrm{N}$-terminal of $\beta$ catenin, which results in the formation of stable bonds between the complex and the actin cytoskeleton. ${ }^{54}$ The binding domain responsible for the link to actin is located at the N-terminal and is also responsible for the linkage of spectrin to the complex..$^{55}$ The formation of the complex does not interfere with the catenins' ability to form complexes with other molecules, both cytoplasmic (such as APC) or at the cell membrane-for example, the EGF receptor (EGFR). ${ }^{45}$ Changes in the linkage to the cytoskeleton may be the mechanism by which $\mathrm{EGF}$ induces alterations in E-cadherin function. ${ }^{56}$ The catenins forming the complex may also be exchanged for free catenins within the cytoplasm. ${ }^{46}$ The final intercellular binding between E-cadherin molecules of adjacent cells 
is calcium mediated and the resultant multimolecular structure has a "zipper" conformation. ${ }^{30}$

Pathological mechanisms effecting cell adhesion mediated by the

\section{E-cadherin-catenin complex}

The E-cadherin-catenin complex is dependent upon numerous interactions, which have been highlighted above. It should be obvious that cell adhesion is thus dependent not only on the structural and functional integrity of the E-cadherin molecule, but also that of the associated catenins and other molecules that mediate its binding to the cytoskeleton. Reduction in cell adhesion is of major importance in tumour metastasis and appears to be achieved by a variety of mechanisms affecting the E-cadherin-catenin complex. These include reduction or loss of E-cadherin expression, mutation of the genes of the constituent molecules, redistribution of E-cadherin to different sites within the cell, shedding of E-cadherin, and competition for binding sites by other proteins. ${ }^{57}$

Reduction or loss of expression of E-cadherin has been documented in a large number of tumours from varying organs, including colon, ${ }^{58} 59$ stomach, ${ }^{206061}$ pancreas, ${ }^{62}$ oesophagus, ${ }^{6364}$ liver, ${ }^{65}$ lung, ${ }^{64} 66$ bladder, ${ }^{67-69}$ prostate ${ }^{70-72}$ breast, ${ }^{73-79}$ uterus, ${ }^{80}$ ovary, ${ }^{81}$ thyroid, ${ }^{82}$ skin and oral carcinomas. ${ }^{83-87}$ The degree of tumour differentiation appears to be related to the proportion of E-cadherin expression, with poorly differentiated tumours more likely to show reduced E-cadherin expression, which might be a result of downregulation or defects in the catenins. ${ }^{6388-90}$

Mutation of the genes of the constituent molecules may result in structural or functional aberrations that result in reduction of cell adhesion. Mutations of the E-cadherin gene appear to be infrequent events. In frame skipping of exon 8 or 9 and deletion of exon 10 have been demonstrated in diffuse-type gastric cancer. ${ }^{91}$ Point mutations in exons 7 (invasive breast carcinoma), ${ }^{92} 12$ and 13 (endometrial carcinoma), ${ }^{93}$ and 16 (ovarian carcinoma) ${ }^{93}$ have also been demonstrated, and these mostly affect the extracellular domain of E-cadherin. Deletions of the $\alpha$ catenin gene, resulting in a mutated $\alpha$ catenin that does not bind E-cadherin, have been identified in lung, colon, and prostate carcinoma cells. ${ }^{70}{ }^{94-96} \beta$ catenin has been found to be deleted in a human gastric carcinoma cell line. ${ }^{88} 90$

Redistribution of E-cadherin expression has been noted in some cancers, with the staining being variable or spotty in distribution, or located at abnormal sites along the membrane. ${ }^{64}{ }^{66}$ Cytoplasmic (as opposed to membranous) expression has been noted in thyroid, breast, and some squamous carcinomas. ${ }^{78} 8297$

Shedding of E-cadherin from the cell surface, with resultant excretion of soluble E-cadherin in the urine has been reported..$^{98}$ In these cases, the primary tumours have been noted to show reduced E-cadherin expression. Bladder cancers have also been shown to be associated with shedding of the molecule into the urine. ${ }^{100}$
Competition for binding to E-cadherin by other molecules such as the APC protein may affect the normal E-cadherin-catenin interaction, thereby resulting in abnormal function. ${ }^{49}{ }^{101-103}$

\section{Functional regulation of E-cadherin expression}

The expression of E-cadherin may be downregulated as part of a physiological process. Embryonic morphogenesis is commonly associated with variations in E-cadherin expression occurring during specific events. ${ }^{104} 105$ An example is found during the development of the murine cochlea, where E-cadherin is downregulated on the lateral membranes of the reticular lamina, allowing the process of fluid space opening in the organ of Corti. ${ }^{106}$ E-cadherin is downregulated during fusion of cytotrophoblast cells to syncytiotrophoblast. ${ }^{107}$ Downregulation has been observed in liver undergoing regeneration after partial hepatectomy. ${ }^{108}$

Downregulation occurring under specific circumstances suggests the existence of external control over the expression of E-cadherin, and thus cell adhesion. Treatment with epidermal growth factor appears to interfere with E-cadherin-catenin complex assembly and results in a more invasive phenotype in vitro. ${ }^{109}$ The interference with complex assembly seems to be mediated by a mitogenic signal transmitted by the EGFR through its tyrosine kinase, resulting in tyrosine phosphorylation of $\beta$ catenin and E-cadherin itself. ${ }^{110}$ Transforming growth factor $\alpha$ (TGF- $\alpha$ ) has extensive homology with EGF, and produces most of the biological activities of EGF, as a result of binding with the EGFR. It has been shown recently that inhibition of E-cadherin, using a specific antibody, results in secretion of a urokinasetype plasminogen activator, which induces proteolysis of the extracellular matrix. ${ }^{111}$ Thus, stimulation of the EGFR results in reduction of E-cadherin function, facilitating cell motility and proteolysis of the extracellular matrix, which would favour cell invasion. Regulation of cell adhesion by EGFR stimulation is also very important in wound healing, where EGF and TGF- $\alpha$ are produced in response to the cascade of active substances released by the injured tissue, allowing the proliferating epithelial cells to migrate, thereby facilitating closure of the breached epithelial layer. This appears to account for the downregulation of E-cadherin seen in epithelial cells adjacent to areas of ulceration in the gastrointestinal tract. ${ }^{112}$

Other motility factors that promote the proliferation and non-directional movement of discohesive cells have been isolated. These include autocrine motility factor (AMF), ${ }^{113}$ migration stimulation factor (MSF), scatter factor/hepatocyte growth factor (SF/HGF), and autotaxin. ${ }^{10} 114$ The SF/HGF receptor, c-Met, is a transmembrane tyrosine kinase and proto-oncogene. ${ }^{115}$ Binding of $\mathrm{SF} / \mathrm{HGF}$ to c-Met appears to mediate mesenchymalepithelial interactions that regulate cell growth, development, motility, and morphogenesis. ${ }^{116117}$ Although the function and interac- 
tion of these factors is beyond the confines of this review, it is clear that they form part of the cascade of active substances released during the process of tissue damage. The motility factors appear to act in concert with other factors, including $\mathrm{EGF}$ and $\mathrm{TGF}-\alpha$, to facilitate a reduction in cell adhesion and increased cell motility, in turn leading to tissue repair and healing. Adhesion molecules expressed by tumour cells could be regulated in a similar way, in response to tumour necrosis.

Several studies have reported that integrins are capable of signal transduction across the plasma membrane, resulting in local changes in cell adhesion and the cytoskeleton, ${ }^{118}$ giving rise to the question of whether E-cadherin itself is involved in signalling. EGF induced signal transduction and its effects have been mentioned previously. Recent studies have revealed an intersection between signalling (WNTwingless pathway) and adhesion (cadherincatenin complex). ${ }^{119}$ The Wnt-1 protein, which has been studied extensively in drosophila, has been found to bind to a seven transmembrane domain receptor called frizzled. The steps in the pathway downstream of membrane binding are still not fully understood; however, $\beta$ catenin is known to be of major importance. The sharing of the cytosolic pool of $\beta$ catenin means that the cadherin/WNT pathways are dependent upon each other. For instance, binding of Wnt-1 to the frizzled receptor results in accumulation of cytoplasmic $\beta$ catenin. ${ }^{120}$ The increased pool of $\beta$ catenin will obviously have an effect on cell adhesion, with the $\beta$ catenin in this cytosolic pool either linking with E-cadherin or acting in the WNTwingless pathway. $\beta$ Catenin may heterodimerise with leucocyte enhancer factor (LEF-1), allowing translocation to the nucleus, where LEF-1 induces DNA bending and gene transcription. ${ }^{121} 122$ The genes activated by the $\beta$ catenin-LEF complex have not been defined.

The view that the E-cadherin-catenin complex might be involved in signalling has been strengthened by the demonstration that homophilic binding of E-cadherin to an adjacent cell can activate protein kinase C, leading to the assembly of tight junctions. ${ }^{123}$ The assembly of tight junctions also involves the Rho subfamily of the Rho small G protein family. ${ }^{124}$ Other members of the G protein family include the Rac and Cdc42 subfamilies, which are involved in regulation of E-cadherin mediated cell-cell adhesion through the action of a molecule known as IQGAP1. ${ }^{125}$ In a recent study, Rho, Rac, and Cdc42 activation by tumour necrosis factor $\alpha(\mathrm{TNF}-\alpha)$ resulted in reorganisation of the actin cytoskeleton and the formation of intercellular gaps, indicating reduced function of tight junctions. ${ }^{126} \mathrm{~A}$ similar effect on endometrial epithelial cells by TNF- $\alpha$ had been noted previously and attributed to disassembly of actin filaments. ${ }^{127}$ The evidence above appears to indicate a role for TNF- $\alpha$ in the regulation of cell adhesion.

The role of the APC protein in the regulation of E-cadherin is not yet fully understood. The APC gene is located on chromosome $5 \mathrm{q}$ and is mutated in familial adenomatous polyposis and in most sporadic colorectal carcinomas. ${ }^{128} 129$ As already mentioned, both wt and mt APC proteins bind to $\alpha$ catenin and $\beta$ catenin. In addition, the wt APC protein, unlike mt APC, has the ability to promote microtubule assembly in vitro. ${ }^{130}$ It has been hypothesised that, based on the selective localisation of the APC protein to the superficial differentiated crypt compartment in gut epithelium, ${ }^{131}$ the wt APC protein may regulate shedding of cells from the luminal surface through its interplay with the E-cadherin-catenin complex, resulting in downregulation of E-cadherin expression. $\mathrm{Mu}-$ tation of APC might result in interference of the normal mechanism, leading to accumulation of cells that contain potentially oncogenic mutations. ${ }^{132}$

The role of Helicobacter pylori in the regulation of E-cadherin has been studied recently. It is widely accepted that $H$ pylori is the main factor in the pathogenesis of peptic ulceration. ${ }^{133}$ In addition, data have emerged recently that implicate this bacterium in the development of gastric cancer and lymphoma. ${ }^{134-136}$ The ulcerogenic potential of $\mathrm{H}$ pylori seems to result from the action of bacterial urease, which generates ammonia and protease that break down the protective mucous layer overlying the gastric epithelium. Recent studies have shown that $H$ pylori infection is associated with downregulation of E-cadherin, probably by generating cell signalling events that counteract the normal function of protein kinase C. ${ }^{137}{ }^{138}$ The resulting increase in permeability mediated by the reduction in cell adhesion might allow $H$ pylori antigens to reach the gastric lamina propria and activate the mucosal immune system, with resultant tissue damage.

The ability of cell adhesion, represented in part by E-cadherin function, to be regulated by a variety of factors implies that the downregulation of E-cadherin seen in certain tumours may not just be a function of genetic mutations, resulting in expression of a dysfunctional, mutated protein, but may be regulated by factors within the microenvironment of the tumour. This modulation of E-cadherin expression has been noted in a recent study of 25 adenocarcinomas by Cowley and Smith. ${ }^{139}$ They found higher levels of E-cadherin expression in the intravascular component of the tumours, compared with the adjacent, much larger extravascular component. It is tempting to speculate that the upregulation noted in the intravascular component may be the result of a relatively higher oxygen tension in this compartment. The effect of this upregulation would be an increase in tumour cell adhesion, facilitating the formation of a tumour embolus.

The interplay of various factors within the tumour microenvironment has been extensively studied recently, particularly in breast cancers. Reduction of E-cadherin expression in invasive duct carcinoma of the breast has been shown to correlate with the presence of lymph node metastasis, invasiveness, and EGFR expression. ${ }^{140} 141$ Poorly differentiated duct carcinoma in situ (DCIS) shows significantly less E-cadherin expression compared with well differentiated DCIS. ${ }^{142}$ The expression of peptide 
growth factors TGF- $\alpha, \mathrm{EGF}$, and insulin-like growth factor I (IGF-I) has been found to be increased in a large proportion of breast carcinomas. ${ }^{143-145}$ Breast stromal cell cultures derived from human breast cancer lines are able to secrete an EGF-like substance, probably as a result of stimulation by the adjacent cancer cells. ${ }^{146}$ These results indicate that the reaction to varying concentrations of stimulatory factors, such as EGF and $\mathrm{TNF}-\alpha$, within the various microenvironments of a tumour affect the degree of cell adhesion, allowing carcinoma in situ to transform into an invasive tumour.

Is there a role for hypoxia in the initiation of the metastatic cascade and downregulation of E-cadherin?

The conventional models of epithelial tumour metastasis start with a cell or population of cells that undergoes a series of mutational events resulting in a malignant population. ${ }^{147}$ These mutations affect oncogenes and tumour suppressor genes, resulting in an uncontrolled proliferation of immortalised cells, which causes further genetic mutations that affect the differentiation of the cell, as well as the structural proteins dictating the interactions with adjacent cells. ${ }^{148}$ The structural aberrations allow the tumour cells to detach from each other, break through the basement membrane, attach to and degrade extracellular matrix components, migrate through the tissue into a vascular channel, and eventually spread to a distant organ to establish a metastasis. With advances in the understanding of the interaction between epithelial cells, it is clear that to generate a clone of cells capable of metastasis, a vast amount of genetic damage is required at a multiplicity of sites.

Although most tumours appear to develop from a single cell, the mutations occurring within the resultant tumour population lead to the development of several phenotypes that differ with respect to their rate of growth, invasiveness, metastatic potential, karyotype, hormonal responsiveness, and resistance to anticancer treatment. This realisation that malignant tumours, although monoclonal in origin, are, at least by the time they manifest clinically, actually a heterogeneous population, has led to extensive study into the "metastatic phenotype". The factor that predisposes the original transformed cell to additional genetic damage is not known, but most researchers favour the notion that the original transformation event renders the cell's genome inherently unstable, making it susceptible to a high rate of spontaneous mutations. ${ }^{149}$

The search for factors that affect the progression and behaviour of tumours has led to the investigation of the effect of the microenvironment on particular tumours. It is now known that the tumour microenvironment can affect the cellular heterogeneity of tumours and this realisation has spawned a number of studies. ${ }^{150}$ Many of them have been conducted in vitro under well controlled conditions; however, the microenvironments produced have not been reproduced in vivo. There have been some in vivo studies that have attempted to identify specific interactions. Drug resistant variants were found to be increased in murine carcinoma cells after exposure to activated macrophages, ${ }^{151}$ whereas progression of hyperplastic alveolar nodules to adenocarcinoma in mice was noted after natural killer cell infiltration of the nodules. ${ }^{152}$ Another microenvironment that occurs in malignant tumours and which is receiving attention is that of hypoxia. Oxygen deprivation seems to be present in almost all malignant tumours. With progressive and rapid growth of the tumour population, the blood supply is outstripped, resulting in cellular ischaemia and eventually the tumour necrosis that is invariably seen in malignant tumours. The effects of this ischaemia are listed below and provide compelling evidence that tumour hypoxia may well be the factor that initiates and promotes the metastatic cascade.

After the development of ischaemia within a tumour, the resultant necrosis leads to the release of infammatory mediators such as cytokines, which recruit polymorphonuclear leucocytes, macrophages, and other cells that participate in the inflammatory process. Macrophages that are recruited to the site of tumour necrosis act in a similar way to those that are present at a site of non-neoplastic tissue damage. One of the factors released by the macrophages is nitric oxide synthetase (NOS), resulting in the formation of nitric oxide (NO), which acts as a free radical and is cytotoxic to tumour cells. It acts by oxidising sulphhydryl groups on proteins and reacting with superoxide anion to form nitrogen dioxide (a strong oxidant) and the highly reactive hydroxyl radical. ${ }^{153}$ The demonstration of increased NOS activity within breast cancers of higher grade suggests that NO may provide a positive growth signal within the hypoxic tumour environment, resulting in increased growth rate, vascular density, and invasiveness. ${ }^{154}$

The peptide growth factors, basic fibroblast growth factor (bFGF) and EGF, have been found to reduce NO mediated neuronal death in the hippocampus after exposure to an anoxic environment. ${ }^{155}$ The reduction in neuronal death implies that these peptide growth factors might have a protective effect on tumour cells exposed to the cytotoxic effects of NO. As has been mentioned previously, EGF is found in breast carcinomas, where it appears to be synthesised by activated stromal cells within the tumours. ${ }^{143-146}$ In addition, experimental work on acute renal injury mediated by hypoxia has revealed that there is induction of mRNA for heparin binding EGF-like growth factor (HB-EGF) ${ }^{156} \mathrm{~A}$ subsequent study by the same group confirmed that HB-EGF was produced in response to acute hypoxic renal injury. ${ }^{157}$ Production of HB-EGF appears to be important in renal epithelial cell repair, proliferation, and regeneration. From these results, it is possible to suggest that the increase in peptide growth factors identified in carcinomas might be the result of the hypoxic injury suffered by the tumour. These growth factors might have a similar protective effect on the tumour cells as they appear to have on hypoxic neurons. This 
protective effect would not only allow a larger percentage of the tumour cells to survive the period of hypoxia before the ingrowth of new vessels, stimulated by angiogenic factors, but would also have the effect of allowing the cells prolonged exposure to the mutagenic effects of the free radicals produced by NO. Thus, once the vascular supply has been re-established by the process of angiogenesis, these cells may have acquired enough genetic mutations over a relatively short period to establish a clone of cells possessing an aggressive malignant phenotype.

In several studies, the effect of a hypoxic environment on DNA synthesis and expression has been investigated. Although DNA synthesis appears to be inhibited by hypoxia, on reoxygenation, the previously arrested cells demonstrate large scale DNA replication. ${ }^{158-160}$ A similar effect has been observed with gene amplification. ${ }^{159} 161$ As a result, it appears that large parts of the genome, including any newly mutated parts (resulting from the damage precipitated as a result of the hypoxia) are amplified in a non-specific manner. In addition, a hypoxia induced increase in metastatic potential, which correlates with the generation of cells with over-replicated DNA, has been demonstrated in murine tumour cells. ${ }^{162}$ The cells that exhibited the highest experimental metastatic efficiency were those that were exposed to the most severe degrees of hypoxia because they were situated furthest away from the vasculature. ${ }^{163}$ More recently, a number of different metastasis associated genes have been studied in various tumour cell lines to try and identify any correlation between increased expression of these genes and metastatic potential. No overall correlation between changes in the mRNA levels for cathepsin B, cathepsin L, nm23, tissue inhibitor of metalloproteinase 1 (TIMP-1), osteopontin, or vascular endothelial growth factor (VEGF) and metastatic ability could be demonstrated. ${ }^{164} \mathrm{~A}$ previous study from the same group using similar cell lines had demonstrated increased cathepsin B and cathepsin L, and increased invasiveness after hypoxia and glucose starvation. ${ }^{165}$ The variation in results obtained in these two studies appears to confirm the random nature of the genetic damage caused by hypoxia.

The random damage demonstrated above is by no means unique, with the literature being littered at the present with numerous studies indicating that a particular genetic mutation is associated with metastasis in a particular carcinoma. However, these findings are inconsistent between different research groups. An example of these differences is the investigation of the metastatic phenotype in squamous carcinomas of the head and neck. Bockmühl et al found that metastasising tumours frequently displayed deletions affecting chromosomes $7 \mathrm{q}$, $10 \mathrm{q}, 11 \mathrm{p}, 15 \mathrm{q}$, and $20 \mathrm{p} .{ }^{166}$ Over-representation of chromosomes $19 \mathrm{q}$ and $20 \mathrm{q}$ were also noted. In comparison, metastasising tumours studied by Carey et al showed patterns of loss affecting chromosomes 3p, 4p, 5q, 8p, 9p, 10p, 13q, 18q, and $21 .{ }^{167}$ Patterns of gain were found in chro- mosomes 1q, 3q, 5p, 7p, and 11q. These conflicting results occurring in a similar tumour population cannot be explained simply by the use of differing methodology and they indicate that the "metastatic phenotype" may not be a distinct pattern of chromosomal aberrations within a specific malignant phenotype, but may be unique to each tumour.

The release of peptide growth factors, such as EGF and TNF- $\alpha$, in response to hypoxia has been mentioned above. The binding of these factors in normal epithelia to the EGFR has been described previously and results in downregulation of E-cadherin and reduced cell adhesion. In the setting of a tumour, this interaction does not appear to be so simple. Reports from recent studies indicate that the binding of peptide growth factors to the EGFR is reduced in the setting of hypoxia. ${ }^{168-170}$ In one of the studies it was found that pretreatment with suramin, which binds to growth factor, resulted in increased tyrosine phosphorylation of the EGFR after exposure to high oxygen tensions. ${ }^{170}$ This suggests that either there is an autocrine effect, or that other factors within the hypoxic environment are stimulating the EGFR, which results in reduced cell adhesion.

The overall effect of hypoxia on tumours appears to affect the prognosis adversely. Well documented examples of this include carcinomas of the head and neck and cervical carcinomas. ${ }^{171} 172$ The presence of hypoxia within these tumours has been associated with increased invasiveness and a propensity to metastasise. Soft tissue sarcomas with reduced oxygen levels have been shown to have a worse prognosis compared with those with higher oxygen tensions. ${ }^{173}$ Other instances where tumours exposed to hypoxia assume a more aggressive phenotype are those tumours that have been subjected to subcurative radiotherapy. ${ }^{174}{ }^{175}$ In this setting, hypoxia appears to be mediated by the vascular changes seen in response to radiotherapy.

From the foregoing evidence, it is hypothesised that the development of tumour hypoxia is the initiating factor that sets the tumour on the road to metastasis. To summarise, a malignant tumour that undergoes uncontrolled growth eventually outstrips its blood supply, resulting in hypoxia and starvation because of a lack of nutrients. The resultant necrosis releases active substances, including cytokines, peptide growth factors, and cytotoxic factors such as NO. The result of this is a population of cells exposed to sublethal ischaemia, which has the effect of reducing cell adhesion, increasing DNA mutations, and stimulating angiogenesis. With the ingrowth of new vessels and reoxygenation of the affected cells, the resultant clone assumes a more aggressive behaviour, as a result of the acquisition of a large number of genomic mutations imparting a "metastatic phenotype". The transformed, poorly adhered cells with reduced E-cadherin expression then have the ideal opportunity to invade adjacent tissue and the newly formed delicate vessels provided by the process of angiogenesis, using previously described mechanisms of the metastatic cascade. Therefore, although the devel- 
opment of hypoxia within the tumour is essential for the initiation and promotion of the metastatic cascade, it is the resultant angiogenic response that allows the tumour to reach its full potential and metastasise.

\section{Conclusion}

The realisation that a reduction in cell-cell adhesion is essential for a malignant tumour to invade and metastasise has led to the identification of several different groups of cell adhesion molecules, of which the cadherins and catenins are important members. The finding that reduction in E-cadherin expression in malignant tumours was associated with a poor prognosis and metastasis led to much research, which has elucidated the structure of this molecule and its interactions and regulatory factors. The understanding of the processes involved in the control of E-cadherin expression, together with the explosion of research aimed at investigating the metastatic cascade, has allowed the formulation of the above hypothesis, which implicates tumour hypoxia as the principal initiator of the metastatic cascade. It is important to remember that the metastatic cascade is a result of complex interactions between numerous factors and that to regard a single factor as being the lynchpin on which all other steps are dependent would be naive. Recent research into angiogenesis inhibitors is exciting and the results produced to date are encouraging. However, they should not be viewed in isolation but rather as part of a multidrug treatment combined with existing chemotherapeutic drugs. At present, work on targeting the cell adhesion system is in its infancy when compared with the progress made in the field of angiogenesis. One possible target area identified here is the peptide growth factors, molecules that exert a protective effect against the hypoxia present within tumours, which in turn seems to facilitate the generation of genomic mutations within tumour cells. Use of a peptide growth factor inhibitor in conjunction with an angiogenesis inhibitor might facilitate the development of lethal hypoxia within the target tumour, eliminating the development of a metastatic clone of cells.

The author thanks Professor K Cooper for critical reading of this manuscript.

1 Recamier JCA. Recherches sur le traitment du cancer par la compression methodique simple ou combinée et sur l'histoire générale de la meme maladie, Vol. 2. Paris: Chez Gabor, 1829:110. Cited by: Wilder RJ. Fournal of Mount Sinai Hospital 1956;23:728-34.

2 Hart IR, Saini A. Biology of tumour metastasis. Lancet 1992;339:1453-7.

3 Mareel M, De Baetselier P, Van Roy F. Mechanisms of invasion and metastasis. Boca Raton: CRC Press, 1991.

4 Günthert U, Birchmeier W, Schlag PM, eds. Attempts to understand metastasis formation. Regulatory factors. Introduction. Curr Top Microbiol Immunol 1996;213:V-VII

5 Bernstein LR, Liotta LA. Molecular mediators of interactions with extracellular matrix components in metastasis and angiogenesis. Curr Opin Oncol 1994;6:106-13.

6 Juliano RL, Varner JA. Adhesion molecules in cancer: the role of integrins. Curr Opin Cell Biol 1993;5:812-18.

7 Ellis V, Pike C, Erikson J, et al. The urokinase receptor: involvement in cell surface proteolysis and cancer invasion. Ann N Y Acad Sci 1992;667:13-31.

8 Liotta LA. Cancer cell invasion and metastasis. Sci Am 1992;266:34-41.

9 Matrisian LM. The matrix-degrading metalloproteinases. Bioessays 1992;14:455-63.
10 Stoker M, Gherardi E. Regulation of cell movement: the motogenic cytokines. Biochim Biophys Acta 1991;1072:81102.

11 Van Roy F, Mareel M. Tumour invasion: effects of cell adhesion and motility. Trends Cell Biol 1992;2:163-9.

12 Nicolson GL. Molecular mechanisms of cancer metastasis tumor and host properties and the role of oncogenes and suppressor genes. Curr Opin Oncol 1991;3:75-92.

13 Baserga R. Oncogenes and the strategy of growth factors. Cell 1994;79:927-30.

14 Folkman J. Angiogenesis in cancer, vascular, rheumatoid and other disease. Nat Med 1995;1:27-31.

15 Liotta LA, Steeg PS, Stetler-Stevenson WG. Cancer metastasis and angiogenesis: an imbalance of positive and negative regulation. Cell 1991;64:327-36.

16 Bussemakers MJG, Schalken JA. The role of cell adhesion molecules and proteases in tumor invasion and metastasis. World f Urol 1996;14:151-6.

17 Birchmeier W, Beherens J. Cadherin expression in carcinomas: role in the formation of cell junctions and the prevention of invasiveness. Biochim Biophys Acta 1994; 198: $11-26$

18 Mareel M, Bracke M, Van Roy F. Invasion promoter versus invasion suppressor molecules: the paradigm of E-cadherin. Mol Biol Rep 1994;19:45-67.

19 Takeishi M. Cadherins in cancer: implications for invasion and metastasis. Curr Opin Cell Biol 1993;5:806-11.

20 Shino Y, Watanabe A, Yamada Y, et al. Clinicopathologic evaluation of immunohistochemical E-cadherin expression in human gastric carcinomas. Cancer 1995;76:2193-201.

21 Tamura S, Shiozaki H, Miyata M, et al. Decreased E-cadherin expression is associated with haematogenous recurrence and poor prognosis in patients with squamous cell carcinoma of the oesophagus. Br F Surg 1996;83:160814.

22 Hunt NCA, Douglas-Jones AG, Jasani B, et al. Loss of E-cadherin expression associated with lymph node metastases in small breast carcinomas. Vichows Arch 1997;430: 285-9.

23 Le Bivic A, Sambuy Y, Mostov K, et al. Vectorial targeting of an endogenous apical membrane sialoglycoprotein and uvomorulin in MDCK cells. F Cell Biol 1990;110:1533-9.

24 Lewis JE, Jensen PJ, Johnson KR, et al. E-cadherin mediates adherens junction organization through protein kinase C. 7 Cell Sci 1995;108:3615-21.

25 Ozawa M, Kemler R. Correct proteolytic cleavage is required for the cell adhesive function of uvomorulin. 7 Cell Biol 1990;111:1645-50.

26 Berx G, Staes K, van Hengel J, et al. Cloning and characterization of the human invasion suppressor gene E-cadherin (CDH1). Genomics 1995;26:281-9.

27 Mansouri A, Spurr N, Goodfellow PN, et al. Characterization and chromosomal localization of the gene encoding the human cell adhesion molecule uvomorulin. Differentiation 1988;38:67-71.

28 Scherer G, Bausch E, Gaa A, et al. Gene mapping on mouse chromosome 8 by interspecific crosses: new data on a linkage group conserved on human chromosome 16q. Genomics 1989;5:275-8.

29 Overduin M, Harvey TS, Bagby S, et al. Solution structure of the epithelial cadherin domain responsible for selective cell adhesion. Science 1995;267:386-9.

30 Shapiro L, Fannon AM, Kwong PD, et al. Structural basis of cell-cell adhesion by cadherins. Nature 1995;374:327-37.

31 Becker JW, Erikson HP, Hoffman S, et al. Topology of cell adhesion molecules. Proc Natl Acad Sci USA 1989;86: 1088-92.

32 Ozawa M, Baribault H, Kemler R. The cytoplasmic domain of the cell adhesion molecule uvomorulin associates with three independent proteins structurally related in different species. EMBO ₹ 1989;8:1711-17.

33 Ozawa M, Ringwald M, Kemler R. Uvomorulin-catenin complex formation is regulated by a specific domain in the cytoplasmic region of the cell adhesion molecule. Proc Natl Acad Sci USA 1990;87:4246-50.

34 Stappert J, Kemler R. A short core region of E-cadherin is essential for catenin binding and is highly phosphorylated. Cell Adhes Commun 1994;2:319-27.

35 Herrenknecht K, Ozawa M, Eckerskorn C, et al. The uvomorulin-anchorage protein alpha catenin is a vinculin homologue. Proc Natl Acad Sci USA 1991;88:9156-60.

36 McCrea PD, Gumbiner BM. Purification of a $92-\mathrm{kDa}$ cytoplasmic protein tightly associated with the cell-cell adhesion molecule E-cadherin (uvomorulin). Characterization and extractability of the protein complex from the cell cytostructure. F Biol Chem 1991;266:4514-20.

37 Knudsen AK, Wheelock MJ. Plakoglobin, or an $83-\mathrm{kD}$ homologue distinct from beta-catenin, interacts with E-cadherin and N-cadherin. $\mathcal{F}$ Cell Biol 1992;118:671-9.

38 McPherson JD, Morton RA, Ewing CM, et al. Assignment of the human alpha-catenin gene (CTNNA1) to chromosome 5q21-22. Genomics 1994;19:188-90

39 Kraus C, Liehr T, Hülsken J, et al. Localization of the human $\beta$-catenin gene (CTNNB1) to $3 \mathrm{p} 21$ : a region implicated in tumor development. Genomics 1994;23:2724.

40 Aberle H, Montagna M, Lynch HT, et al. The human plakoglobin gene localizes on chromosome $17 \mathrm{q} 21$ and is subjected to loss of heterozygosity in breast and ovarian cancers. Proc Natl Acad Sci USA 1995;92:6384-8.

41 Reynolds AB, Daniel J, McCrea PD, et al. Identification of a new catenin: the tyrosine kinase substrate p120cas
associates with E-cadherin complexes. Mol Cell Biol 1994;14:8333-42. 
42 Reynolds AB, Jenkins NA, Gilbert DJ, et al. The gene encoding p120cas, a novel catenin, localizes on human (Catns). Genomics 1996;31:127-9.

43 Shibamoto S, Hayakawa M, Taceuchi K, et al. Association of p120, a tyrosine kinase substrate, with E-cadherin/catenin complexes. F Cell Biol 1995;128:949-57.

44 Jou TS, Stewart DB, Stappert J, et al. Genetic and biochemical dissection of protein linkages in the cadherincatenin complex. Proc Natl Acad Sci USA 1995;92:506771.

45 Näthke IS, Hinck L, Swedlow JR, et al. Defining interactions and distributions of cadherin and catenin complexes in polarized epithelial cells. 7 Cell Biol 1994;125:1341-52.

46 Hinck L, Näthke IS, Papkoff J, et al. Dynamics of cadherin catenin complex formation: novel protein interactions and catenin complex formation: novel protein interactions and 40 .

47 Butz S, Kemler R. Distinct cadherin/catenin complexes in Ca (2+)-dependent cell-cell adhesion. FEBS Lett 1994; 355:195-200

$48 \mathrm{Su}$ LK, Vogelstein B, Kinzler KW. Association of the APC tumor suppressor protein with catenins. Science 1993;262: 1734-7.

49 Rubinfeld B, Souza B, Albert I, et al. Association of the APC gene product with beta-catenin. Science 1993;262:1731-4.

50 Daniel JM, Reynolds AB. The tyrosine kinase substrate p120cas binds directly to E-cadherin but not to the adenomatous polyposis coli protein or alpha-catenin. Mol Cell miol 1995;15:4819-24.

51 Hinck L, Nelson WJ, Papkoff J: Wnt-1 modulates cell-cell adhesion in mammalian cells by stabilizing $\beta$-catenin binding to the cell adhesion protein cadherin. $\mathcal{F}$ Cell Biol 1994 124:729-41.

52 Ochiai A, Akimoto S, Kanai Y, et al. c-erbB-2 gene product associates with catenins in human cancer cells. Biochem Biophys Res Commun 1994;205:73-8.

53 Nagafuchi A, Takeichi M. Transmembrane control of cadherin-mediated cell adhesion: a $94 \mathrm{kDa}$ protein functionally associated with a specific region of the cytoplasmic region of E-cadherin. Cell Regul 1990;1:37-44.

54 Aberle H, Butz S, Stappert J, et al. Assembly of the cadherin-catenin complex in vitro with recombinant proteins. f Cell Sci 1994;107:3655-63.

55 Lombardo CR, Rimm DL, Koslov E, et al. Human recombinant alpha-catenin binds to spectrin. Mol Biol Cell 1994; 5(suppl):47a.

56 Hoschuetzky H, Aberle H, Kemler R. $\beta$-catenin mediates the interaction of the cadherin-catenin complex with epidermal growth factor receptor. F Cell Biol 1994;127: 1375-80.

57 Jiang WG. E-cadherin and its associated protein catenins, cancer invasion and metastasis. Br F Surg 1996;83:437-46.

58 Van Aken J, Cuvelier CA, De Wever N, et al. Immunohistochemical analysis of E-cadherin expression in human colorectal tumours. Pathol Res Pract 1993;189:975-8.

59 Dorudi S, Sheffield JP, Poulsom R, et al. E-cadherin in colorectal cancer. An immunocytochemical and in situ colorectal cancer. An immunocytochemical and
hybridization study. Am F Pathol 1993;142:981-6.

60 Yasui W, Kuniyasu H, Akama Y, et al. Expression of E-cadherin, alpha-, and beta-catenins in human gastric carcinomas: correlation with histology and tumor progression. Oncology Reports 1995;2:111-17.

61 Mayer B, Johnson JP, Leitl F, et al. E-cadherin expression in primary and metastatic gastric cancer: down-regulation correlates with cellular dedifferentiation and glandular disintegration. Cancer Res 1993;53:1690-5.

62 Pignatelli M, Ansari TW, Gunter P, et al. Loss of membranous E-cadherin expression in pancreatic cancer: correlation with lymph node metastasis, high grade, and advanced stage. F Pathol 1994;174:243-8.

63 Kadowaki T, Shiozaki $\mathrm{H}$, Inoue $\mathrm{M}$, et al. E-cadherin and alpha-catenin expression in human esophageal cancer. Cancer Res 1994;54:291-6.

64 Bongiorno PF, al-Kasspooles M, Lee SW, et al. E-cadherin expression in primary and metastatic thoracic neoplasm and in Barrett's oesophagus. Br f Cancer 1995;71:166-72.

65 Slagle BL, Zhou YZ, Birchmeier W, et al. Deletion of the E-cadherin gene in hepatitis B virus-positive Chinese hepatocellular carcinomas. Hepatology 1993;18:757-62.

66 Bohm M, Totzeck B, Birchmeier W, et al. Differences of E-cadherin expression levels and patterns of primary human lung cancer. Clin Exp Metastasis 1994;12:55-62.

67 Bringuier PP, Umbas R, Schaafsma HE, et al. Decreased E-cadherin immunoreactivity correlates with poor survival
in patients with bladder tumors. Cancer Res 1993;53:3241in pati

68 Otto T, Birchmeier W, Schmidt U, et al. Inverse relation of E-cadherin and autocrine motility factor receptor expression as a prognostic factor in patients with bladder carcinomas. Cancer Res 1994;54:3120-3.

69 Dorkin TJ, Robson CN, Neal DE. The molecular pathology of urological malignancies. F Pathol 1997;183:380-7.

70 Morton RA, Ewing CM, Nagafuchi A, et al. Reduction of E-cadherin levels and deletion of the alpha-catenin gene in human prostate cancer cells. Cancer Res 1993;53:3585-90.

71 Umbas R, Isaacs WB, Bringuier PP, et al. Decreased E-cadherin expression is associated with a poor prognosis in patients with prostate cancer. Cancer Res 1994;54:392933 .

72 Otto T, Rembrink K, Goepel M, et al. E-cadherin: a marker for differentiation and invasiveness in prostatic carcinoma. Urol Res 1993;21:359-62.
73 Takayama T, Shiozaki H, Inoue $M$, et al. Expression of E-cadherin and alpha-catenin molecules in human breast E-cadherin and alpha-catenin molecules in human breast cancer tissues and association with

74 Moll R, Mitze M, Frixen UH, et al. Differential loss of E-cadherin expression in infiltrating ductal and lobular carcinomas. Am f Pathol 1993;143:1731-42.

75 Palacios J, Benito N, Pizarro A, et al. Anomalous expression of P-cadherin in breast carcinoma. Correlation with E-cadherin expression and pathological features. $\mathrm{Am} f$ Pathol 1995;146:605-12.

76 Gamallo C, Palacios J, Suarez A, et al. Correlation of E-cadherin expression with differentiation grade and histological subtype in breast carcinoma. Am F Pathol 1993;142: 987-93.

77 Oka H, Shiozaki H, Kobayashi K, et al. Expression of E-cadherin cell adhesion molecules in human breast cancer tissues and its relationship to metastasis. Cancer Res 1993; (is:

78 Rasbridge SA, Gillett CE, Sampson SA, et al. Epithelial (E-) and placental (P-) cadherin cell adhesion molecule expression in breast carcinoma. F Pathol 1993;169:245-50.

79 De Leeuw WJF, Berx G, Vos CBJ, et al. Simultaneous loss of E-cadherin and catenins in invasive lobular breast cancer and lobular carcinoma in situ. F Pathol 1997;183:404-11.

80 Sakuragi $\mathrm{N}$, Nishiya $\mathrm{M}$, Ikeda $\mathrm{K}$, et al. Decreased E-cadherin expression in endometrial carcinoma is associated with tumor dedifferentiation and deep myometrial invasion. Gynecol Oncol 1994;53:183-9.

81 Veatch AL, Carson LF, Ramakrishnan S. Differential expression of the cell-cell adhesion molecule E-cadherin in ascites and solid human ovarian tumor cells. Int 7 Cancer 1994;58:393-9.

82 Brabant G, Hoang-Vu C, Ceti Y, et al. E-cadherin: a differentiation marker in thyroid malignancies. Cancer Res 1993; 53:4987-93.

83 Pizarrro A, Benito N, Navarro P, et al. E-cadherin expression in basal cell carcinoma. Br f Cancer 1994;69: $157-62$

84 Sakaki T, Wato M, Kaji R, et al. Correlation of E- and $\mathrm{P}$-cadherin expression with differentiation grade and mode of invasion in gingival carcinoma. Pathol Int 1994;44:280-

85 Mattijssen V, Peters HM, Schalkwijk L, et al. E-cadherin expression in head and neck squamous-cell carcinoma is associated with clinical outcome. Int $\mathcal{F}$ Cancer 1993;55: $580-5$

86 Nicholson LJ, Pei XF, Watt FM. Expression of E-cadherin, P-cadherin and involucrin by normal and neoplastic keratinocytes in culture. Carcinogenesis 1991;12:1345-9.

87 Andrews NA, Jones AS, Helliwell TR, et al. Expression of the E-cadherin-catenin adhesion complex in primary squamous cell carcinomas of the head and neck and their nodal metastases. Br F Cancer 1997;75:1474-80.

88 Kawanishi J, Kato J, Sasaki K, et al. Loss of E-cadherindependant cell-cell adhesion due to maturation of the $\beta$-catenin gene in a human cancer cell line, HSC-39. Mol Cell Biol 1995;15:1175-81.

89 Navarro P, Lozano E, Cano A. Expression of E- or P-cadherin is not sufficient to modify the morphology and tumorigenic behavior of murine spindle carcinoma cells. Possible involvement of plakoglobin. F Cell Sci 1993;105: 923-34.

90 Oyama T, Kanai Y, Ochiai A, et al. A truncated beta-catenin disrupts the interaction between E-cadherin and alphacatenin: a cause of loss of intercellular adhesiveness in human cancer cell lines. Cancer Res 1994;54:6282-7.

91 Becker KF, Atkinson MJ, Reich U, et al. Exon skipping in the E-cadherin gene transcript in metastatic human gastric carcinomas. Hum Mol Genet 1993;2:803-4.

92 Kanai Y, Oda $\mathrm{T}$, Tsuda $\mathrm{H}$, et al. Point mutation of the E-cadherin gene in invasive lobular carcinoma of the breast. Fpn f Cancer Res 1994;85:1035-9.

93 Risinger JI, Berchuck A, Kohler MF, et al. Mutations of the E-cadherin gene in human gynecologic cancers. Nat Genet

94 Shimoyama Y, Nagafuchi A, Fujita S, et al. Cadherin dysfunction in a human cancer cell line: possible involvement of loss of alpha-catenin expression in reduced cell-cell adhesiveness. Cancer Res 1992;52:5770-4.

95 Oda T, Kanai Y, Shimoyama Y, et al. Cloning of the human alpha-catenin cDNA and its aberrant mRNA in a human cancer cell

96 Breen E, Clarke A, Steele G, Jr, et al. Poorly differentiated colon carcinoma cell lines deficient in catenin expression express high levels of surface E-cadherin but lack Cell Adhes Commun 1993;1:239-50.

97 Inoue $M$, Ogawa $H$, Miyata $M$, et al. Expression of E-cadherin in normal, benign, and malignant tissues of female genital organs. Am f Clin Pathol 1992;98:76-80.

98 Katayama M, Hirai S, Yasumoto M, et al. Soluble fragments of E-cadherin cell adhesion molecule increase in urinary excretion of cancer patients, potentially indicating its shedding from epithelial tumor cells. Int f Oncol 1994;5:104957.

99 Katayama M, Hirai S, Kamihagi K, et al. Soluble E-cadherin fragments increased in circulation of cancer patients. $\mathrm{Br} \mathcal{F}$ Cancer 1994;69:580-5.

100 Banks RE, Porter WH, Whelan P, et al. Soluble forms of the adhesion molecule E-cadherin in urine. $\mathcal{F}$ Clin Pathol 1995;48:179-80. 
101 Hulsken J, Birchmeier W, Behrens J. E-cadherin and APC compete for the interaction with $\beta$-catenin and the compete for the interaction with $\beta$-c
cytoskeleton. $\mathcal{F}$ Cell Biol 1994;127:2061-9.

102 De Benedetti L, Sciallero S, Gismondi V, et al. Association of APC gene mutations and histological characteristics of colorectal adenomas. Cancer Res 1994;54:3553-6.

103 Miyaki M, Konishi M, Kikuchi-Yanoshita R, et al. Characteristics of somatic mutation of the adenomatous polyposis coli gene in colorectal tumors. Cancer Res 1994;54:301120.

104 Reima I, Lehtonen E, Virtanen I, et al. The cytoskeleton and associated proteins during cleavage, compaction and blastocyst differentiation in the pig. Differentiation 1993;54: 35-45.

105 Crossin KL, Chuong CM, Edelman GM. Expression sequences of cell adhesion molecules. Proc Natl Acad Sci USA 1985;82:6942-6.

106 Whitlon DS. E-cadherin in the mature and developing organ of Corti of the mouse. $\mathcal{F}$ Neurocytol 1993;22:1030-8

107 Coutifaris C, Kao L-C, Sehdev HM, et al. E-cadherin expression during the differentiation of human trophoblasts. Development 1991;113:767-77.

108 Gluck U, Rodriguez-Fernandez JL, Pankov R, et al. Regulation of adherens junction protein expression in growthactivated 3T3 cells and in regenerating liver. Exp Cell Res 1992;202:477-86.

109 Shiozaki H, Kadowaki T, Doki Y, et al. Effect of epidermal growth factor on cadherin-mediated adhesion in a human oesophageal cancer cell line. Br F Cancer 1995;71:250-8.

110 Shiozaki $\mathrm{H}$, Oka $\mathrm{H}$, Inoue $\mathrm{M}$, et al. E-cadherin mediated adhesion system in cancer cells. Cancer 1996;77(suppl): 1605-13.

111 Fixen UH, Nagamine Y. Stimulation of urokinase-type plasminogen activator expression by blockage of Elasminogen activator expression by blockage of 53:3618-23.

112 Dogan A, Wang ZD, Spencer J. E-cadherin expression in intestinal epithelium. F Clin Pathol 1995;48:143-6.

113 Nabi IR, Watanabe H, Raz A. Autocrine motility factor and its receptor: role in cell locomotion and metastasis. Cancer Metastasis Rev 1992;11:5-20.

114 Ruiz P, Günthert U. The cellular basis of metastasis. World f Urol 1996;14:141-50.

115 Boros P, Miller CM. Hepatocyte growth factor: a multifunctional cytokine. Lancet 1995;345:293-5.

116 Birchmeier C, Birchmeier W. Molecular aspects of mesenchymal-epithelial interactions. Annu Rev Cell Biol 1993;9:511-40.

117 Rosen EM, Nigam SK, Goldberg ID. Scatter factor and the c-Met receptor: a paradigm for mesenchymal/epithelial the c-Met receptor: a paradigm for mesench

118 Damsky $\mathrm{CH}$, Werb Z. Signal transduction by integrin receptors for extracellular matrix: cooperative processing of
extracellular information. Curr Opin Cell Biol 1992;4:77281 .

119 Moon RT, Brown JD, Torres M. WNTs modulate cell fate and behaviour during vertebrate development. Trends Genet 1997;13:157-63.

120 Hunter T. Oncoprotein networks. Cell 1997;88:333-46.

121 Berhens J, von Kleis JP, Kuhl $\mathrm{M}$, et al. Functional interaction of $\beta$-catenin with the transcription factor LEF-1. Nature 1996;382:638-42.

122 Buckley CD, Simmons DL. Cell adhesion: a new target for therapy. Mol Med Today 1997;3:449-56.

123 Balda MS, Gonzalez-Mariscal L, Matter K, et al. Assembly of the tight junction: the role of diacylglycerol. $f \mathrm{Cell}$ Bio 1993;123:293-302.

124 Takaishi K, Sasaki T, Kotani H, et al. Regulation of cell-cell adhesion by $\mathrm{rac}$ and rho small $\mathrm{G}$ proteins in cell-cell adhesion by rac and rho small

125 Kuroda S, Fukata M, Nakagawa M, et al. Role of IQGAP1, a target of the small GTPases Cdc42 and Rac1, in regulation of E-cadherin-mediated cell-cell adhesion. Science 1998;281:832-5

126 Wojciak-Stothard B, Entwistle A, Garg R, et al. Regulation of TNF-alpha-induced reorganization of the actin cytoskeleton and cell-cell junctions by Rho, Rac, and Cdc42 in human endothelial cells. F Cell Physiol 1998;176:150-65.

127 Tabibzadeh S, Kong QF, Kapur S, et al. Tumour necrosis factor-alpha-mediated dyscohesion of epithelial cells is associated with disordered expression of cadherin/betacatenin and disassembly of actin filaments. Hum Reprod 1995;10:994-1004

128 Powell SM, Zilz N, Beazer-Barclay Y, et al. APC mutations occur early during colorectal tumorigenesis. Nature 1992; occur early

129 Bodmer W, Bishop T, Karran P. Genetic steps in colorectal cancer [news]. Nat Genet 1994;6:217-19.

130 Smith KJ, Levy DB, Maupin P, et al. Wild-type but not mutant APC associates with the microtubule cytoskeleton. Cancer Res 1994;54:3672-5.

131 Smith KJ, Johnson KA, Bryan TM, et al. The APC gene product in normal and tumor cells. Proc Natl Acad Sci USA 1993;90:2846-50.

132 Smith MEF, Pignatelli M. The molecular histology of neoplasia: the role of the cadherin/catenin complex. Histopathology 1997;31:107-11.

133 Cover T, Blaser M. Helicobacter pylori and gastroduodenal disease. Anпu Rev Med 1992;43:135-145.

134 Correa P. Helicobacter pylori and gastric carcinogenesis. Am F Surg Pathol 1995;19(suppl 1):S37-43.

135 Isaacson PG. Recent developments in our understanding of gastric lymphomas. Am f Surg Pathol 1996;20(suppl 1):S1-7.
136 Wotherspoon AC. Helicobacter pylori infection and gastric lymphoma. Br Med Bull 1998;54:79-85.

137 Terrés AM, Pajares JM, O'Toole D, et al. H pylori infection is associated with downregulation of E-cadherin, a molecule involved in epithelial cell adhesion and proliferation control. F Clin Pathol 1998;51:410-12.

38 Terrés AM, Pajares JM, Hopkins AM, et al. Helicobacter pylori disrupts epithelial barrier function in a process nhibited by protein kinase C activators. Infect Immun 1998;66:2943-50

139 Cowley GP, Smith ME. Modulation of E-cadherin expression and morphological phenotype in the intravascular component of adenocarcinomas. Int $\mathcal{F}$ Cancer 1995;60:325-9.

140 Jones JL, Royall JE, Walker RA. E-cadherin relates to EGFR expression and lymph node metastasis in primary breast carcinoma. Br f Cancer 1996;74:1237-41.

141 Siitonen SM, Kononen JT, Helin HJ, et al. Reduced E-cadherin expression is associated with invasiveness and unfavorable prognosis in breast cancer. Am $\mathcal{F}$ Clin Pathol 1996;105:394-402.

142 Gupta SK, Douglas-Jones AG, Jasani B, et al. E-cadherin E-cad) expression in duct carcinoma in situ (DCIS) of the breast. Virchows Arch 1997;430:23-8.

143 Pilichowska M, Kimura N, Fujiwara H, et al. Immunohistochemical study of TGF- $\alpha$, TGF- $\beta$, EGFR, and IGF- 1 expression in human breast carcinoma. Mod Pathol 1997;10:969-75.

144 Panico L, D'Antonio A, Salvatore G, et al. Differential immunohistochemical detection of transforming growth factor $\alpha$, amphiregulin, and CRIPTO in normal and malignant breast tissue. Int 7 Cancer 1996;65:51-6.

145 Toropainen E, Lipponen P, Syrjanen K. Expression of insulin-like growth factor 1 (IGF-1) in female breast cancer as related to established prognostic factors and long-term prognosis. Eur f Cancer 1995;31:1443-8.

146 Sainsbury JRC, Hirst EA, Needham GK, et al. Fibroblast cell lines derived from human breast cancers have epidermal growth factor receptors and produce an epidermal growth factor-like molecule [abstract]. $\mathrm{Br} \mathcal{F}$ Cancer 1985;52:440.

147 Fidler IJ, Hart IR. Biological diversity in metastatic neoplasms: origins and implications. Science 1982;217: 998-1003.

148 Nicholson GL. Generation of phenotypic diversity and progression in metastatic tumor cells. Cancer Metastasis Rev $1984 ; 3: 25-42$.

149 Hill RP. Tumor progression: potential role of unstable genomic changes. Cancer Metastasis Rev 1990;9:137-47.

50 Olsson L. Phenotypic diversity of malignant cell populations: molecular mechanisms and biological significance. Cancer Rev 1986;3:91-114.

151 Yamashima K, Miller BE, Heppner GH. Macrophagemediated induction of drug-resistant variants in a mouse mammary tumour cell line. Cancer Res 1986;46:2396-401.

152 Wei W, Fulton A, Winkelhake J, et al. Correlation of natural killer activity with tumorigenesis of a preneoplastic

53 Moncada S, Palmer RM, Higgs A. Nitric oxide: physiolog pathophysiology, and pharmacology. Pharmacol Rev 1991; 43:109-42.

154 Thomsen LL, Miles DW. Role of nitric oxide in tumour progression: lessons from human tumours. Cancer Metastasis Rev 1998;17:107-18.

155 Maiese K, Boniece I, DeMeo D, et al. Peptide growth factors protect against ischemia in culture by preventing nitric oxide toxicity. F Neurosci 1993;13:3034-40.

156 Homma T, Sakai M, Cheng HF, et al. Induction of heparin-binding epidermal growth factor-like growth factor mRNA in rat kidney after acute injury. $\mathcal{f}$ Clin Invest 1995;96:1018-25.

157 Sakai M, Zhang M, Homma T, et al. Production of heparin binding epidermal growth factor-like growth factor in the early phase of regeneration after acute renal injury. Isolation and localization of bioactive molecules. $\mathcal{F}$ Clin Invest 1997;99:2128-38.

158 Shrieve DC, Begg AC. Cell cycle kinetics of aerated, hypoxic and re-aerated cells in vitro using flow cytometric determination of cellular DNA and incorporated bromodeoxyuridine. Cell Tissue Kinet 1985;18:641-51.

159 Rice GC, Hoy C, Schimke RT. Transient hypoxia enhances the frequency of dihydrofolate reductase gene amplification in Chinese hamster ovary cells. Proc Natl Acad Sci USA 1986;83:5978-82.

160 Loffler M. Restimulation of cell cycle progression by hypoxic tumour cells with deoxynucleosides requires ppm xygen tension. Exp Cell Res 1987;169:255-61.

161 Rice GC, Ling V, Schimke RT. Frequencies of independent and stimulation selection of Chinese hamster cells for methotrexate and deoxyrubicin (adriamycin) resistance. Proc Natl Acad Sci USA 1987;84:9261-4.

162 Young SD, Marshall RS, Hill RP. Hypoxia induces DNA overreplication and enhances metastatic potential of murin tumor cells. Proc Natl Acad Sci USA 1988;85:9533-7.

163 Young SD, Hill RP. Effects of reoxygenation on cells from hypoxic regions of solid tumours: anticancer drug sensitivity and $371-80$.

164 Jang A, Hill RP. An examination of the effects of hypoxia, acidosis, and glucose starvation on the expression of metastasis-associated genes in murine tumour cells. Clin Exp Metastasis 1997;15:469-83.

165 Cuvier C, Jang A, Hill RP. Exposure to hypoxia, glucose starvation and acidosis: effect on invasive capacity of 
murine tumor cells and correlation with cathepsin $(\mathrm{L}+\mathrm{B})$ secretion. Clin Exp Metastasis 1997;15:19-25.

166 Bockmint U, Petersen S, Schmidt S, et al. Patterns of chromosomal alterations in metastasizing primary head and neck carcinomas. Cancer Res 1997;57:5213-16.

167 Carey TE, Frank CJ, Raval JR, et al. Identifying genetic changes associated with tumour progression in squamous cell carcinoma. Acta Otolaryngol (Stockh) 1997;529(suppl): 229-32.

168 Hirose $\mathrm{T}$, Terajima H, Yamauchi A, et al. Oxygen dependency of epidermal growth factor receptor binding and DNA synthesis of rat hepatocytes. F Hepatol 1997;27:10818 .

169 Falanga V, Takagi H, Ceballos PI, et al. Low oxygen tension decreases receptor binding of peptide growth factors in dermal fibroblast cultures. Exp Cell Res 1994;213:80-4

170 Nici L, Medina M, Frackelton AR. The epidermal growth factor receptor network in type 2 pneumocytes exposed to
hyperoxia in vitro. Am $\mathcal{F}$ Physiol 1996;270:L242-50.
171 Sundfor K, Lyng H, Rofstad EK. Tumour hypoxia and vascular density as predictors of metastasis in squamous cell carcinoma of the uterine cervix. $\mathrm{Br} f$ Cancer 998;78:822-7

172 Brizel DM, Sibley GS, Prosnitz LR, et al. Tumor hypoxia dversely affects the prognosis of carcinoma of the head and neck. Int $\mathcal{F}$ Radiat Oncol Biol Phys 1997;38:285-9.

173 Brizel DM, Scully SP, Harrelson JM, et al. Tumor oxygenation predicts for the likelihood of distant metastases in human soft tissue sarcoma. Cancer Res 1996;56: tases in

174 Ramsay J, Suit HD, Sedlacek R. Experimental studies on the incidence of metastases after failure of radiation treatment and the effect of salvage surgery. Int $\mathcal{F}$ Radiat Oncol Biol Phys 1988;14:1165-8.

175 Nathanson SD, Westrick P, Anaya P, et al. Relationship of spontaneous regional lymph node metastases to dose of local irradiation of primary B16 melanomas. Cancer Res 1989;49:4412-16. 